\title{
Evaluation of lead and cadmium in Torkay (Schizothorax plagiostomus) of Indus River at Swabi, KPK, Pakistan
}

\author{
Irfan $\mathrm{Ali}{ }^{*}$, Ihtisham Ur Rahman ${ }^{1}$, Muhammad Uzair ${ }^{2}$ and Mohsin Khan ${ }^{3}$ \\ 1. Department of Zoology, University of Swabi-Pakistan \\ 2. Department Food science and Technology, The University of agriculture Peshawar-Pakistan \\ 3. Department of poultry science, The University of Agriculture Peshawar-Pakistan \\ *Corresponding author's email: irfanalbdrian@gmail.com
}

Citation

Irfan Ali, Ihtisham Ur Rahman, Muhammad Uzair and Mohsin Khan. Evaluation of lead and cadmium in Torkay (Schizothorax plagiostomus) of Indus River at Swabi, KPK, Pakistan. Pure and Applied Biology. Vol. 9, Issue 3, pp1954-1961. http://dx.doi.org/10.19045/bspab.2020.90208

\begin{tabular}{llll}
\hline Received: 13/02/2020 & Revised: 16/05/2020 & Accepted: 29/05/2020 & Online First: 01/06/2020 \\
\hline
\end{tabular}

\section{Abstract}

The study was performed to analyze the heavy metals; cadmium and lead concentration in different tissue of Torkay (Schizothorax plagiostomus) for three months collected from Indus River at three different sites Kund, Jehangira and Ala Dair, District Swabi, Khyber Pakhtunkhwa. In February, concentration of cadmium $(\mathrm{Cd})$ were maximum in gill tissue ( $0.03 \mathrm{gm})$ followed by swim bladder ( $0.02 \mathrm{gm})$ and muscle ( $0.01 \mathrm{gm})$ while lead were not detected in any tissue. Similarly in March, concentration of $\mathrm{Cd}$ were maximum in gill tissue $(0.05 \mathrm{gm})$ followed by swim bladder $(0.40 \mathrm{gm})$ and muscle no data (N.D). While in this month lead were maximum in muscle $(0.02 \mathrm{gm})$ followed by swim bladder $(0.01 \mathrm{gm})$ and muscle (N.D). Likewise in April, concentration of cadmium were maximum in gill tissue $(0.04 \mathrm{gm})$ followed by muscle $(0.03 \mathrm{gm})$ and swim bladder (N.D). In this month lead $(\mathrm{pb})$ concentration were maximum in gill tissue $(0.06 \mathrm{gm})$ followed by swim bladder $(0.02 \mathrm{gm})$ and muscle $(0.01 \mathrm{gm})$. Concluding that $\mathrm{Cd}$ and $\mathrm{Pb}$ were maximum accumulated in gill tissue $(\mathrm{Cd}=0.03 \mathrm{gm}-0.05 \mathrm{gm}$ and $\mathrm{Pb}=0-0.06 \mathrm{gm})$, followed by muscle $(\mathrm{Cd}=0.01 \mathrm{gm}-0.03 \mathrm{gm}$ and $\mathrm{Pb}=0-0.03 \mathrm{gm})$ and swim bladder $(\mathrm{Cd}=0-0.04 \mathrm{gm}$ and $\mathrm{Pb}=0-0.02 \mathrm{gm})$. Similarly maximum cadmium was observed in March followed by April and February while maximum lead was observed in April followed by March and February. This research reviewing that accumulation of lead and cadmium has no beneficial effects inside the body of Tokay but cause severe health problems in fish as well as in human being and other aquatic organism.

Keywords: Cadmium; Indus River; Lead; Swabi; Torkay

\section{Introduction}

Metals are seen as major biological toxic substances as they are non-biodegradable, cytotoxic, mutagenic, and malignant growth causing in nature [1]. Presence of metal contaminations particularly the heavy metals become increases in naturally occurring things present in environment, has become an issue of increasing in marine biological systems. These conditions has ascended because of the fast development of population, mechanical development and arrival of untreated modern technologies, expanded urbanization, extension of regular assets, addition of water system and other current cultivating practices just as the 
absence of natural standards [2]. It is an overall issue and has made genuine health concerns [3]. Metals tend to collect in different tissues of the fish, which thus may go into the human digestion through utilization causing health problems [4] Heavy metals are steady and decided ecological contaminations of both fresh and marine water bodies. Use of metals like iron $(\mathrm{Fe})$, zinc $(\mathrm{Zn})$ and manganese $(\mathrm{Mn})$, which are fundamental for functioning in living organisms, found in narrow range between their healthy and adverse ratio. Other heavy metals like mercury ( $\mathrm{HG})$, cadmium $(\mathrm{Cd})$, chromium $(\mathrm{Cr})$ and lead $(\mathrm{Pb})$ may show extraordinary hazard even in minute ratio under specific conditions, consequently requiring customary checking of delicate oceanic situations [5]. The basic metals like copper, zinc, iron and cobalt have imperative natural capacities in living life forms at the ratios, which permit the compounds frameworks to work irrespectively of impedance. The centralizations of follow metals are particularly higher in the fauna than in water. Be that as it may, because of excess of contaminations in the water if the focus levels of these follow components increment past the level required by the life form they will cause abnormalities after exposure [6]. Heavy metals like $\mathrm{Cr}, \mathrm{Zn}, \mathrm{Cd}$, $\mathrm{Pb}$ and nickel (Ni) and so on, are a portion of the principle segments of modern industrialization, which alongside different items from mechanical procedures are passed into the rivers. These substances are harmful to amphibian life [7, 8]. Metals tend to assemble in various organs of the amphibian creatures, particularly fish, which thus may go into the human assimilation through usage causing serious disorder and abnormalities [9]. The bio-accumulation and bioamplifications of heavy metals in living forms illustrate the procedures for toxins starting with one trophic level to another. Different species fish are generally utilized as bio-markers of heavy metals pollution [10] The acidic states of oceanic condition may make free divalent particles of numerous heavy metals be consumed by fish gills [11]. The groupings of heavy metals in organs of fish show that the sea-going condition is dirtied [12]. Heavy metals accumulations in the amphibian life form depict the past just as the flow contamination load in the earth in which the living being lives [13]. In Pakistan contamination of heavy metals in Indus River is a significant issue. In contrast to human activities ashore, water and air add to the soil of River Indus in Pakistan. The length of Indus River is $970,000 \mathrm{~km}$ seepage bowl zone is one of the overall's principle release and residues present in River. It is polluted with modern and residential sewage. Modern industrialization (concrete and squeezing, manures and flour factories) has additionally expanded the degree of contamination by the arrival of untreated waste items into the River Indus [14]. Heavy metals incorporate cadmium, lead, mercury, these are show up in the association's rundown of top 10 substance of significant open concern likewise it additionally incorporate other model manganese, silver, chromium, nickel, copper, selenium, thallium and antimony [15]. The residues of basic metals exceed from permissible level it become a harmful [16]. Lead $(\mathrm{Pb})$, cadmium $(\mathrm{Cd})$, mercury $(\mathrm{Hg})$ and arsenic (As) are broadly scattered in nature however they have no useful impacts and homoeostasis metal in human body [17]. Toxicologically relevant element lead was added by man to the environment in extreme amount [18]. Lead enters though run off in to water system industrial and sewage wastes streams. If the concentration of lead in water increases, this can damage some aquatic life as well as blood nervous change in animal and fish and others [19]. Lead also damage the central nervous system brain, kidney, liver, and reproductive system in human as well as fish [20] Lead is the most dangerous 
heavy metals. The natural impacts of sublethal centralizations of lead incorporate undeveloped improvement, suppress proliferation and respiratory problems, expanded mucous arrangement, neurological issues, protein synthesis and kidney malfunctioning [21]. Cadmium is transmitted to air by mines, enterprises utilizing cadmium mixes for composite, batteries and metal smelter, shades and in plastics [22]. Tobacco usage as smoke is one of the main cause of cadmium introduction in human. On account of the assimilation of cadmium from lungs a lot more noteworthy than from the gastrointestinal tract, smoking contributes fundamentally to the body problems. Because of the assimilation of cadmium from lungs much faster and greater than from the gastrointestinal tract, smoking supply remarkably to the total body burden [23]. Cadmium can damage reproductive capacity and kidney function in fish [24]. Cadmium also damage several organs in human body liver, lungs, bones and central nervous system [25].

\section{Materials and methods \\ Materials}

During collection of fish the following materials were used. Fishing rod, Nets, Dragon nets, Hook nets, Gloves, Tissue papers, Masks, Formalin, Plastic bottles, Freezing box, Desiccator, Funnel, Beakers, Graduated Cylinder, Scalpel handles (No.4), Scalpel blades (No.22), Forceps, Distilled water, Pipette, Flasks (100ml), Hot palate, Fume hood, Acids (Nitric acid $\left(\mathrm{HNO}_{3}\right)$, per chloric acid $\left(\mathrm{HClO}_{4}\right)$, Analytical balance, Oven, Kjeldehl flask (100ml), Plastic disposable weighting dishes, Watch glass and Filter papers.

\section{Methodology}

After collection and identification of the fish sample was weighted and then preserved in plastic bottle having $4 \%$ formaldehyde and $96 \%$ water solution. The sample was brought to laboratory for dissection after preservation. For dissection of fish sample gloves and mask were used for performing dissection precisely and neatly. Fish was washed with distal water and three different parts (muscle tissue, swim bladder and gill tissue) were dissected with scalpel handle. After dissection each tissues sample were kept in labeled sterilized polythene sampling bags and stored in freezing box having temperature of $-5^{0} \mathrm{C}$ to $-6^{0} \mathrm{C}$. Before weighting, the tissue samples (muscle tissue, swim bladder and gill tissue) were kept for some time after taken out from freezing box so that it become soft and easily cut with scalpel blades. Plastic pincers and plastic spatulas were used to grip the tissue samples. The tissues were weighted by using analytical balance. Plastic disposable weighting dishes were used, If the overall tissue is not to be used for examination, it is carried from the sample container to a disposable PE dish where it is pieces with plastic forceps. During weighting of tissue samples, china dish was placed on analytical balance and tare the balance by pressing tare button. Then the tissue samples were weighted one by one using separate china dish for each tissue sample. Tissue sample was weighted maximum up to 1 gm adjust by using scalpel blades for cutting tissues. After weighting, the sample weights were recorded. In wet digestion the weighted tissue samples were transfer to beaker $(100 \mathrm{ml})$. The beaker was rinsed with distilled water, keeps for about 10 to 15 minutes in oven for drying at temperature of $100^{\circ} \mathrm{C}$ and then kept in desiccator for dryness before use. Plastic forceps was used to transfer tissue samples from china dish to beaker. Solution of Nitric acid $\left(\mathrm{HNO}_{3}\right)$ and Per Chloric acid $\left(\mathrm{HClO}_{4}\right)$ were prepared with 3 to 1 ratio in graduated cylinder $(100 \mathrm{ml})$ by using dropping pipette. About $25 \mathrm{ml}$ solution was added to each beaker by using dropping pipette and placing watch glass on beaker to prevent from hazard fumes produced by digestion of tissue 
samples. The tissue samples were then put on hot palate in fume hood. Fume hood is used to protect against toxic fumes that are produced as a result of digestion and exhaust hazards fumes outside. The tissue samples were heated up to $200{ }^{0} \mathrm{C}$ to $250{ }^{\circ} \mathrm{C}$ until a pale yellow or watery white solution is obtained. Distilled water was added gradually to samples for preventing it from drying. After digestion the tissue samples were placed for cooling to a room temperature. After digestion, through filter paper the tissue samples were filtered in a flask $(100 \mathrm{ml})$. Distilled water was added to make the solution $25 \mathrm{ml}$. The tissue samples were ready for heavy metals analysis $(\mathrm{Cd}$ and pb) through atomic absorption spectrophotometer and the following results were obtained.

\section{Lead concentration in three months}

Lead concentration was maximum in gill tissue in all three month and maximum lead concentration was observed in April (60.00 $\mu \mathrm{g} / \mathrm{Kg}$ ), followed by March and February and mean value is $20.00 \mu \mathrm{g} / \mathrm{Kg}$ as shown in (Table 1, Fig. 1).

After gills tissue, Lead concentration was more in swim bladder tissue, and maximum lead was observed in April $20.00 \mu \mathrm{g} / \mathrm{Kg}$ followed by March and February and mean value is $10.00 \mu \mathrm{g} / \mathrm{Kg}$ as shown (Table 1, Fig. 1).

After swim bladder, Lead concentration was more in muscle tissue and maximum lead concentration was observed in March (20.00 $\mu \mathrm{g} / \mathrm{Kg})$ followed by April $(10.00 \mu \mathrm{g} / \mathrm{Kg})$ and February (ND) and mean value is 10.00 $\mu \mathrm{g} / \mathrm{Kg}$ as shown in (Table 1, Fig. 1).

The result as shown in (Table 1) indicated that the lead concentrations in different fish organs were in permissible limit indicated by

WHO.

\section{Results}

Table 1. Comparison of lead concentration in February, March and April

\begin{tabular}{|c|c|c|c|c|c|}
\hline Tissue Parts & February & March & April & Mean & Unit \\
\hline Gill tissue & N.D & N.D & 60.0 & 20.0 & $\mu \mathrm{g} / \mathrm{Kg}$ \\
\hline Swim Bladder & N.D & 10.0 & 20.0 & 10.0 & $\mu \mathrm{g} / \mathrm{Kg}$ \\
\hline Muscle & N.D & 20.0 & 10.0 & 10.0 & $\mu \mathrm{g} / \mathrm{Kg}$ \\
\hline
\end{tabular}

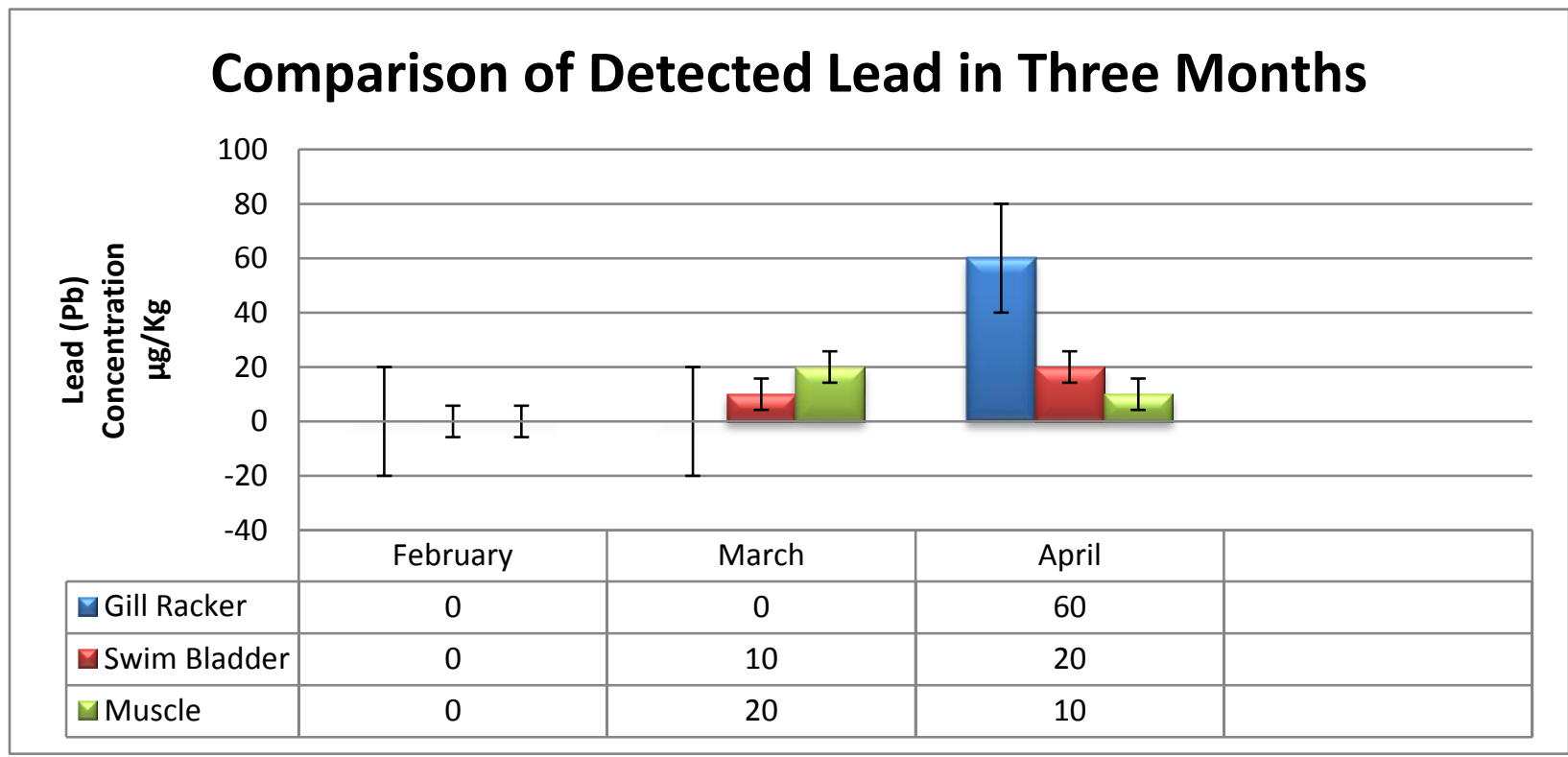

Figure 1. Comparison of lead concentration in February, March and April 
Cadmium concentration in three months

Cadmium concentration was maximum in gill tissue in all three month and maximum cadmium concentration was observed in March $(50.0 \mu \mathrm{g} / \mathrm{Kg})$, followed by April (40.0 $\mu \mathrm{g} / \mathrm{Kg})$ and February $(30.0 \mu \mathrm{g} / \mathrm{Kg})$ and mean value is $40 \mu \mathrm{g} / \mathrm{Kg}$, as shown (Table 2, Fig. 2). After gill tissue, Cadmium concentration was more in swim bladder tissue and observed in March $(40.0 \mu \mathrm{g} / \mathrm{Kg})$ followed by February $(20.0 \mu \mathrm{g} / \mathrm{Kg})$ and April (ND) and mean value was $20 \mu \mathrm{g} / \mathrm{Kg}$, as shown (Table 2, Fig. 2).

After swim bladder tissue, maximum cadmium concentration in muscle tissues was observed in April $(30.0 \mu \mathrm{g} / \mathrm{Kg})$, followed by February $(10.0 \mu \mathrm{g} / \mathrm{Kg}$ ) and March (ND) and mean value was $13.33 \mu \mathrm{g} / \mathrm{Kg}$, as shown (Table 2, Fig. 2).

The result given in (Table 2) indicated that the cadmium concentrations of metals in different fish organs were in permissible limit indicated by WHO.

Table 2. Comparison of cadmium concentration in February, March and April

\begin{tabular}{|c|c|c|c|c|c|}
\hline Tissue Parts & February & March & April & Mean & Unit \\
\hline Gill tissue & 30.0 & 50.0 & 40.0 & 40 & $\mu \mathrm{g} / \mathrm{Kg}$ \\
\hline Swim Bladder & 20.0 & 40.0 & N.D & 20 & $\mu \mathrm{g} / \mathrm{Kg}$ \\
\hline Muscle & 10.0 & N.D & 30.0 & 13.33 & $\mu \mathrm{g} / \mathrm{Kg}$ \\
\hline
\end{tabular}

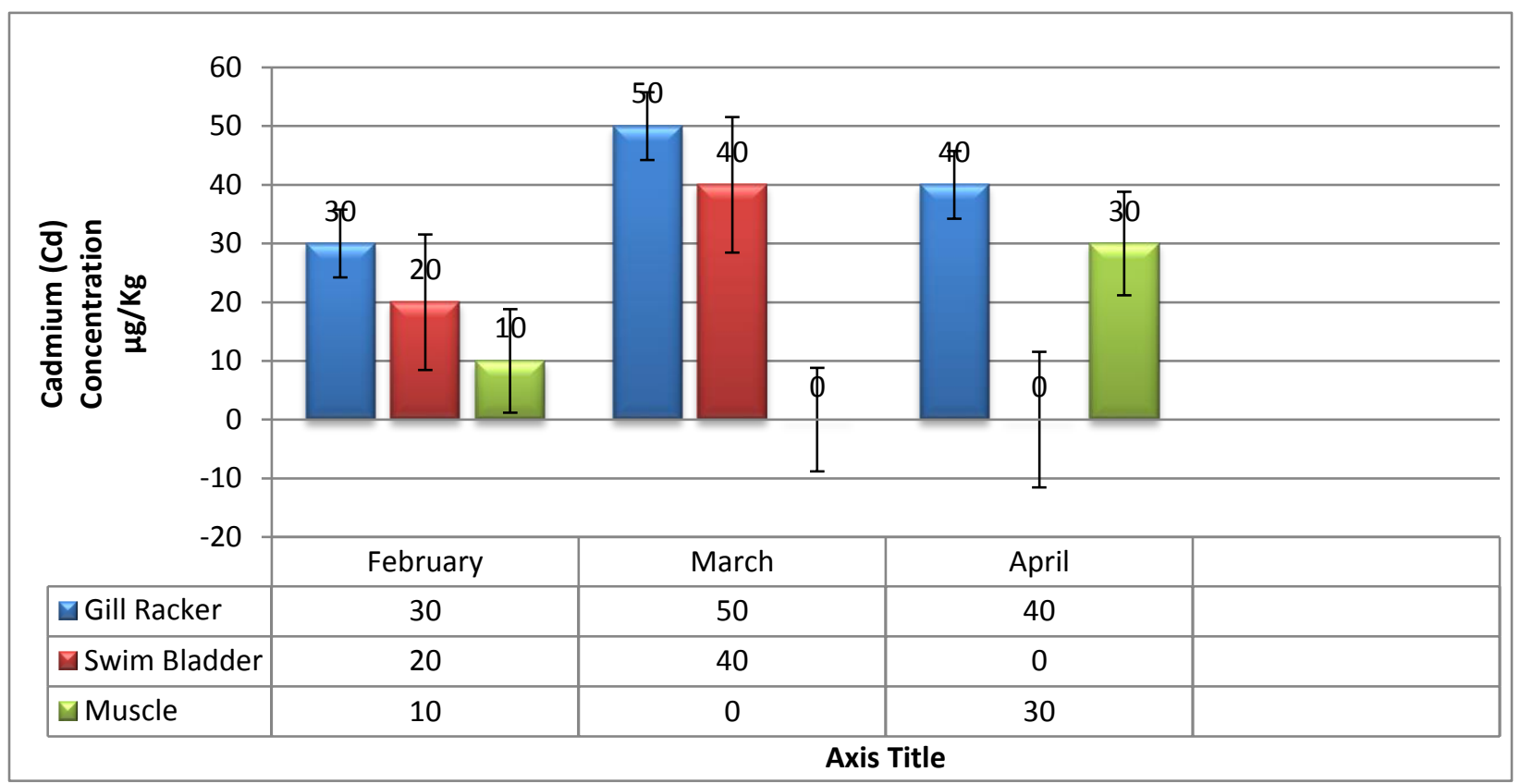

Figure 2. Comparison of cadmium concentration in February, March and April

\section{Discussion}

The study was performed to examine out in three different area of Indus River in the month of February, March and April. Fish were sampled from three different sites of Indus River that is Kund, Jehangira and Ala Dair. In February fish sample was sampled from Kund, in March fish sample was sampled from Jehangira and in April fish sample was sampled from Ala Dair. Lead and Cadmium were detected in gills, swim bladder and muscles of Schizothorax plagiostomus fish collected from River Indus. The accumulation of heavy metals such as lead with mean value $(20.0 \mu \mathrm{g} / \mathrm{Kg})>$ swim bladder, and muscle tissue $(10.0 \mu \mathrm{g} / \mathrm{Kg})$ similarly cadmium $(40.0 \mu \mathrm{g} / \mathrm{Kg}) \quad>$ $(20.0 \mu \mathrm{g} / \mathrm{Kg})>(13.33 \mu \mathrm{g} / \mathrm{Kg})$ were more 
found in the gills of all samples of various months from River Indus since gills are taken as the huge site for direct take-up of metals from the water [26]. $\mathrm{Pb}$ and $\mathrm{Cd}$ are suitable as a remarkable and dangerous metals gathering and $\mathrm{Pb}$ has no known role in biochemical procedures. These metals have a high risk for bio-fixation in fish and are collect in various organs. As a rule, $\mathrm{Pb}$ levels in teleost muscle tissue are extensively lower than in live [27]. Lead is profoundly toxics to aquatic biota, particularly fish [21]. The impacts of sublethal doses of lead incorporate stunt early stage modifications, abnormal reproduction and inhalation problems, expanded mucous secretion, neurological issues and kidney malfunctioning [28]. As per [29] heavy metals, for example, chromium $(\mathrm{Cr})$, nickel $(\mathrm{Ni})$, cadmium $(\mathrm{Cd})$ and lead $(\mathrm{Pb})$ were investigated in various organs like gills, liver, kidney and muscle of the control Common carp fish getting by in regular water framework. They saw that grouping of lead and cadmium in gills was more when contrasted with swim bladder and muscles. [30] Conducted study in River Zaveir situated in western Iran for the reason to distinguish heavy metal focuses in two fishes including Common carp. They recognized heavy metals like lead, mercury, cadmium, copper and nickel in gills, swim bladder and muscles of Schizothorax plagiostomus. Copper and lead were distinguished more in their investigation in all fish organs while cadmium was less in all fish organs. As per [31] heavy metals assemble in fresh water and raise through natural way of life and fishes are influenced because of primary consumer in aquatic food chain. People are likewise influenced by utilization of fishes for most peoples of those territories where principle nourishment source are fishes. Their investigation propose that cadmium and mercury harm the kidney and cause organ malfunctioning including disabled kidney work, poor regenerative limit, hypertension, tumors and hepatic brokenness in the greater part of the fishes. At the point when human take fish in their food having more cadmium concentration, so cadmium will be first moved to the liver through the blood. There, it is connection to proteins synthesis complex that are passed on to the kidneys. Cadmium aggregates in kidneys, where it harms normal functioning of kidney. This causes the end of fundamental proteins and sugars from the body and further kidney harm. It requires some investment before cadmium that as gathered in kidneys is discharged from a human body. Other human impacts that can be brought about by cadmium consumption by human are diarrhea, severe vomiting, bone fracture, failure in reproduction \& infertility, stomach pain, cause damage to central nervous system, mutilation to immune system, mutilation to DNA, cancer development. The heavy metals identified in analysis of Schizothorax plagiostomus were varying. $\mathrm{Cd}$ and $\mathrm{Pb}$ found in the fish tests were underneath the admissible points according to the WHO/FAO rule guidelines manual. Some heavy metals were seen in fish tissues sampled from the Ala Dair inspecting site were ascribed to probably high concentration of metals because of contamination from the mechanical exercises, Municipal and modern wastes, leachate interruption, accordingly, expanding the potential bioavailability to the fish and furthermore representing the related dangers of influencing the quality human healthy lifestyle, just as fish profitability .Our present investigation uncovered that most extreme accumulation of heavy metals like lead and cadmium was seen in gills when contrasted with other tissue. Along these lines, heavy metals when released into the Indus River enter the natural pecking order and collect in the fish body as decided all through this examination. 


\section{Conclusion}

In this study, levels of heavy metals (Lead and Cadmium) were found lower than W.H.O guidelines. It was observed that maximum cadmium was observed in fish tissue collected in March followed by April and February while maximum lead was observed in a sample collected in April followed by March and February. The lead and Cadmium concentration in all tissues sample were minimum with varying concentration in tissues as well as sample selection sites of Indus River. The presence of the trace metallic elements i.e Lead and Cadmium studied in all tissues does not exceed the maximum permissible values. Therefore a regular monitoring schedule and health education should be given in those sites where fish tissues have high levels of heavy metals. Anthropogenic wastes are highly degradable and easily dissolve with air, which can disperse and contaminate water easily, result in increased risk of pollution in water that in turn adversely affect fishes. Regular government (EPA) monitoring should be introduced to improve environmental condition. The present study presents information to the health professionals and the consumers regarding health risk assessments of heavy metals in distribution network of streams and rivers. This can be applied for future quality monitoring and planning.

\section{Authors' contributions}

Conceived and designed the experiments: I Ali, IU Rahman \& M Khan, Performed the experiments: I Ali, IU Rahman, Analyzed the data: I Ali, M Uzair, Contributed materials/ analysis/ tools: I Ali, IU Rahman, M Khan \& M Uzair, Wrote the paper: I Ali \& IU Rahman.

\section{References}

1. More TG, Rajput RA \& Bandela N (2003). Impact of Heavy metals on DNA Contents in the whole body of fresh water Bivalve, Lamellidens marginalis. Pollut Res 22(4): 605-611.
2. Yousafzai AM \& Shakoori AR (2007). Heavy metal bioaccumulation in the muscles of Mahaseer, Tor putitora, as an evidence of heavy metal pollution in River Kabul, Pakistan. Pak J of Zool 39(1).

3. Galindo L, Hardisson A \& Montelongo FG (1986). Correlations between lead, cadmium, copper, zinc, and iron concentrations in frozen tuna fish. Bull Environ. Contam. Toxicol (United States) 36(4).

4. Yousafzai AM \& Shakoori AR (2008). Heavy metal accumulation in the gills of an endangered South Asian fresh water fish as an indicator of aquatic pollution. Pak J of Zool 40(6): 423-430.

5. Fatoki OS \& Mathabatha S (2001). An assessment of heavy metal pollution in the East London and Port Elizabeth harbours. Water SA 27(2): 233-240.

6. Gulfraz M, Ahmad T \& Afal H (2001). Concentration levels of heavy and trace metals in the fish and relevant water from Rawal and Mangla lakes. J Biol Sci 1: 414416.

7. Dutton MD, Majewski HS \& Klaverkamp JF (1988). Biochemical stress indicators in fish from lakes near a metal smelter. In Internat. Assoc. Great Lakes Res 31st Conf.

8. Bowlby JN, Gunn JM \& Liimatainen VA (1988). Metals in stocked lake trout (Salvelinus namaycush) in lakes near Sudbury, Canada. Water, Air and Soil Pollut 39(1-2): 217-230.

9. Puel D, Zsuerger N \& Breittmayer JP (1987). Statistical assessment of a sampling pattern for evaluation of changes in mercury and zinc concentrations in Patella coerulea. Bull Environ Contam Toxicol 38: 700-706.

10. Svobodova Z, Celechovska, O, Kolarova J, Randak T \& Zlabek V (2004). Assessment of metal contamination in the upper reaches of the Tichá Orlice River. Czech J of Animal Sci-UZPI (Czech Republic).

11. Pärt P, Svanberg O \& Kiessling A (1985). The availability of cadmium to perfused 
rainbow trout gills in different water qualities. Water Res 19(4): 427-434.

12. Farkas A, Salanki J \& Varanka I (2000). Heavy metal concentrations in fish of Lake Balaton. Lakes \& Reser: Res \& Manag 5(4): 271-279.

13. Ravera O, Cenci R, Beone GM, Dantas M \& Lodigiani P (2003). Trace element concentrations in freshwater mussels and macrophytes as related to those in their environment. J of Limnol 62(1): 61-70.

14. Jabeen F \& Chaudhry AS (2010). Monitoring trace metals in different tissues of Cyprinus carpio from the Indus River in Pakistan. Environ monit and Asses 170(1-4): 645-656.

15. Harvey PJ, Handley HK \& Taylor MP (2015) Project 1094-15" by TasWater and Water Res Aus.

16. Wright DA \& Welbourn P (2002). Environ toxicol (Vol 11). Cambridge University Press.

17. Simeonov LI, Kochubovski MV \& Simeonova BG (Eds.). (2010). Environ heavy metal pollut and effects on child mental development: Risk assess and preven strategies. Springer.

18. Sesli E, Tuzen M \& Soylak M (2008). Evaluation of trace metal contents of some wild edible mushrooms from Black sea region, Turkey. J of Hazard Mats 160(23): 462-467.

19. Atchison GJ, Henry MG \& Sandheinrich MB (1987). Effects of metals on fish behavior: a review. Environ Biol $J$ of Fishes 18(1): 11-25.

20. Bremner HA (Ed) (2002). Safety and qual issues in fish processing. Elsevier.

21. Rompala JM, Rutosky FW \& Putnam DJ "Con- centrations of Environmental Contaminants from Selected Waters in Pennsylvania," US Fish and Wildlife Service. Special Scie Rep, State College, Pennsylvania (1984).

22. Kalay M, Ay O \& Canli M (1999). Heavy metal concentrations in fish tissues from the Northeast Mediterranean Sea. Bull of Environ Contam and Toxicol 63(5): 673681.

23. Ademoroti CMA (1996). Standard methods for water and effluents analysis. Ibadan: Foludex Press Ltd 3: 29118.

24. Watson D (Ed.) (2001). Food Chemical Safety: Vol 1: Contam (Vol 1). Wood head publishing.

25. Figueroa E (2008). Are more restrictive food cadmium standards justifiable health safety measures or opportunistic barriers to trade? An answer from economics and public health. Sci of the Total Environ 389(1): 1-9.

26. Roméo M, Siau Y, Sidoumou Z \& Gnassia-Barelli M (1999). Heavy metal distribution in different fish species from the Mauritania coast. Sci of the Total Environ 232(3): 169-175.

27. Wagner A \& Boman J (2003). Biomonitoring of trace elements in muscle and liver tissue of freshwater fish. Spectrochimica Acta Part B: Atomic Spectro 58(12): 2215-2226.

28. Rauf A, Javed M \& Ubaidullah M (2009). Heavy metal levels in three major carps (Catla catla, Labeo rohita and Cirrhina mrigala) from the river ravi, pakistan. Pak Vet $J$ 29(1).

29. Vinodhini R \& Narayanan M (2008). Bioaccumulation of heavy metals in organs of fresh water fish Cyprinus carpio (Common carp). Int J of Environ Sci \& Tech 5(2): 179-182.

30. Maleki A, Azadi NA, Mansouri B, Majnoni F, Rezaei Z \& Gharibi F (2015). Health risk assessment of trace elements in two fish species of Sanandaj Gheshlagh Reservoir, Iran. Toxicol and Environ Health Sci 7(1): 43-49.

31. Afshan S \& GardnerL (2013). The continuous strength method for structural stainless steel design.Thin-Walled Struc 68: 42-49. 